\title{
Review of species of the genus Macropsis Lewis, 1836 (Homoptera: Auchenorrhyncha: Cicadellidae: Eurymelinae: Macropsini) of Mongolia based on materials of the Soviet-Mongolian zoological expeditions: annotated check-list, illustrated key to species, and new synonym
}

\author{
Обзор видов рода Macropsis Lewis, 1836 (Homoptera: Auchenorrhyncha: \\ Cicadellidae: Eurymelinae: Macropsini) Монголии по материалам \\ Советско-Монгольских зоологических экспедиџий: \\ аннотированный список, иАлюстрированный кАюч ААя \\ определения видов и новый синоним
}

\section{D.Yu. Tishechkin \\ A.Ю. Тишечкин}

\footnotetext{
Department of Entomology, Faculty of Biology, M.V. Lomonosov Moscow State University, Vorobyevy Gory, Moscow 119234, Russia. Email: macropsis@yandex.ru

Кафедра энтомологии Биологического факультета Московского государственного университета имени М.В. Ломоносова, Воробьёвы Горы, Москва 119234, Россия.
}

KEY WORDS: Homoptera, Auchenorrhyncha, Cicadellidae, Macropsis, Mongolia, annotated check-list, new synonym, key to species.

КЛЮЧЕВЫЕ СЛОВА: Ноmoptera, Auchenorrhyncha, Cicadellidae, Macropsis, Монголия, аннотированный список, новый синоним, определительный ключ.

ABSTRACT. An annotated check-list of 18 species of Macropsis found in Mongolia, an illustrated key for their identification, and distribution maps for each species are provided. The synonymy $M$. cerea (Germar, $1837)=$ M. kaahemica Vilbaste, 1980, syn. n. is established.

РЕЗЮМЕ. Приведён аннотированный список 18 видов Macropsis, найденных в Монголии, иллюстрированный ключ для их определения и карты распространения каждого вида. Установлена синонимия $M$. cerea $($ Germar, 1837) $=$ M. kaahemica Vilbaste, 1980, syn. n.

\section{Introduction}

Intensive study of the entomofauna of Mongolia began in the second half of XX century. For several years, expeditions of Russian and Western European specialists worked on the territory of this country. The main part of the obtained data on Auchenorrhyncha (Homoptera) including annotated lists was published by Dlabola [1965, 1966, 1967a-d, 1968a-b, 1970] and
Emelyanov [1972, 1977, 1982]. Nevertheless, the information on the tribe Macropsini (Homoptera: Auchenorrhyncha: Cicadellidae: Eurymelinae), which was poorly studied in those years and is difficult for taxonomy, remained very incomplete.

Thanks to the courtesy of Prof. Alexander Emelyanov and Dr. Vladimir Gnezdilov I had the opportunity to study the materials on Macropsini from Mongolia collected in the $60 \mathrm{~s}-70$ s of the XX century by SovietMongolian expeditions and deposited in the Zoological Institute of the Russian Academy of Sciences, St.-Petersburg, Russia. The results of these studies are presented below.

Macropsini are represented in Mongolia by three genera. The genus Oncopsis Burmeister, 1838 includes in Mongolia two species, O. tristis (Zetterstedt, 1840) and $O$. burjatica Tishechkin, 2008. The genus Macropsidius Ribaut, 1952 is represented in Mongolia by six species; data on these species are given in our recent review of this genus [Tishechkin, 2014].

This article provides an annotated check-list of species of Macropsis Lewis, 1836 of Mongolia, an illustrated key for their identification, and distribution

How to cite this article: Tishechkin D.Vu. 2020. Review of species of the genus Macropsis Lewis, 1836 (Homoptera: Auchenorrhyncha: Cicadellidae: Eurymelinae: Macropsini) of Mongolia based on materials of the Soviet-Mongolian zoological expeditions: annotated check-list, illustrated key to species, and new synonym // Russian Entomol. J. Vol.29. No.4. P.350-360. doi: 10.15298/rusentj.29.4.02 
maps for each species. Identification of Macropsis species is very difficult due to minor interspecific morphological differences on one side, and variability of morphological traits, on another. Therefore, unlike most other leafhoppers, some species of Macropsis differ in coloration better than in the shape of male genitalia and abdominal apodemes. For this reason, we give colour photos of all species and drawings of only main diagnostic traits; more detailed illustrated descriptions of these species can be found in Tishechkin [1999, 2002].

\section{Material and methods}

The drawings of male genitalia were made by tracing the outlines of digital photographs on a glass table lighted from underneath. The distribution maps were produced using free software from www.simplemappr.net.

Materials studied are deposited in the collections of the Zoological Institute of the Russian Academy of Sciences, St. Petersburg (materials from Mongolia) and Zoological Museum of M.V. Lomonosov Moscow State University (materials from the adjacent territories of Russia and Kazakhstan).

\section{Annotated check-list of Macropsis species of Mongolia}

The order of species groups in the list follows Tishechkin [2016]. After valid names only synonyms absent in Nast [1972] are given. Species which are absent in the studied materials from Mongolia but potentially can be found in this country are listed without numbers.

Species dwelling on Salicaceae. The largest group including 12 species in Mongolia.

\section{Macropsis fuscinervis (Boheman, 1845)} Figs 1, 30-32, 79-82.

DISTRIBUTION. Transpalaearctic within a forest zone. Known from one locality in North-eastern Mongolia (Fig. 1). HOST. Populus tremula L.

Macropsis suspecta Tishechkin, 1994

DISTRIBUTION. Eastern Kazakhstan, Southern Siberia, the Russian Far East. Can be found in Northern Mongolia.

HOST. Poplars from the section Tacamachaca; in the adjacent to Mongolia regions of Southern Siberia feeds on $P$. laurifolia Ledeb. and P. suaveolens Fischer.

REMARK. Dlabola [1965] records the European poplarfeeding species, M. graminea v. populi Edwards, 1919 from two localities in Central Aimak of Mongolia. Apparently, these records should be referred to M. fuscinervis or $M$. suspecta.

\section{Macropsis daurica Tishechkin, 1997}

$$
\text { Figs 1, 21-22, 68-69. }
$$

DISTRIBUTION. Rare species known from several localities in South-eastern Transbaikalia and Amur Oblast and from one locality in Northern Mongolia (Fig. 1).
HOST. In Russia dwells on Salix nipponica Franch. et Savat. (sometimes regarded as a subspecies of $S$. triandra L.; section Amygdalinae) growing on alluvial sediments on the banks of large rivers of the Amur Basin (the Ingoda and the Onon Rivers in Transbaikalia, the Zeya River in Amur Oblast).

\section{Macropsis microcera Vilbaste, 1980}

Figs 1, 18-20, 65-67.

DISTRIBUTION. Eastern half of European Russia, Southern Siberia eastwards as far as the Baikal Lake; Northwestern Mongolia (Fig. 1).

HOST. Willows from the section Viminella: $S$. viminalis L., S. gmelinii Pallas.

\section{Macropsis ochotonaria Tishechkin, 1994}

Figs 2, 12-15, 59-61.

DISTRIBUTION. Southern Siberia from Tyva to Transbaikalia, Amur Oblast (valley of the Zeya River), Northern Mongolia (Fig. 2).

HOST. Willows from the section Helix: S. ledebouriana Trautv., S. miyabeana Seemen.

REMARKS. Distinctly differs from closely related $M$. leporina Tishechkin, 1997 in the male calling signal pattern and host specialisation, but is indistinguishable from it in morphological traits. Thus, identification of collection material without exact data on host plant is impossible. For this reason, we provide common distribution map, drawings and photos for these two species.

Dlabola [1965, 1967b, d] records the European species, M. marginata (Herrich-Schäffer, 1836) from Central Aimak of Mongolia. Judging by the drawings in Dlabola [1965], these records should be referred to $M$. ochotonaria or $M$. leporina. The reason for misidentification could be the fact that these two species have the same range of colour variations as $M$. marginata, including very distinctive blackyellow form (Figs 12-15).

\section{Macropsis leporina Tishechkin, 1997}

Figs 2, 12-15, 59-61.

DISTRIBUTION. Transbaikalia, southern part of the Russian Far East, Northern Mongolia (Fig. 2).

HOST. Willows from the section Viminella: S. schwerinii E.L. Wolf, S. udensis Trautv. et C.A. Mey.

REMARK. See remarks on M. ochotonaria above.

\section{Macropsis tarbagataica Mityaev, 1971} Figs 2, 23-24, 70-72.

DISTRIBUTION. Kazakhstan, Central Asia (Tien Shan and Alay Mtn. Systems); reaches Southern Urals, Russia in the extreme northwest of the range and the western half of Mongolia in the extreme northeast (Fig. 2).

HOST. In Kazakhstan and Central Asia was found on Salix alba L. (section Salix) and on several species from the section Helix. In Southern Urals, Russia one series of specimens was collected from $S$. viminalis (section Viminella).

\section{Macropsis iliensis Mityaev, 1971}

Figs 3, 16-17, 62-64.

Macropsis tuvensis Vilbaste, 1980: 24-25 [synonymy by Tishechkin, 2020].

DISTRIBUTION. Kazakhstan, Central Asia (Northern and Central Tien Shan Mts.); reaches Southern Urals, Russia in the extreme northwest of the range and Southern Siberia (Tyva) and Western Mongolia in the extreme northeast (Fig. 3). 
HOST. In Kazakhstan and Central Asia was found on Salix turanica Nasarow (section Viminella); in Southern Siberia (Tyva) was found on $S$. viminalis (also from the section Viminella); in Southern Urals the only series of specimens was collected from S. vinogradovii A.K. Skvortsov (section Helix).
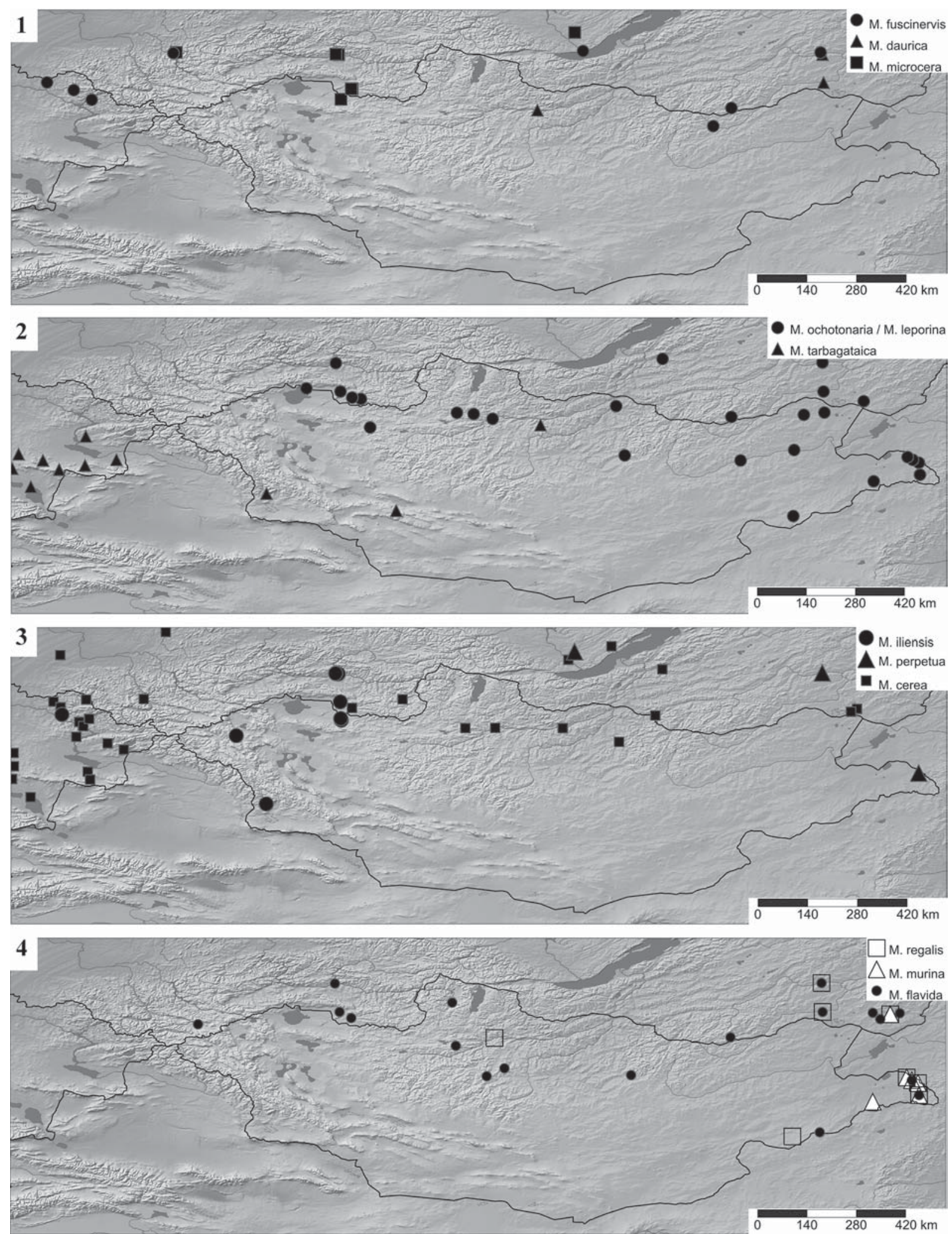

Figs 1-4. Maps of distribution of species of Macropsis in Mongolia and adjacent territories.

Рис. 1-4. Карты распространения видов рода Macropsis в Монголии и на сопредельных территориях. 
Macropsis prasina (Boheman, 1852)

DISTRIBUTION. Europe, Siberia eastwards up to the Baikal Lake, Eastern Kazakhstan. Can be found in Northwestern Mongolia.

HOST. Salix cinerea L. (section Cinerella), sometimes also $S$. viminalis (section Viminella).

\section{Macropsis perpetua Tishechkin, 1996}

Figs 3, 25, 73-74.

DISTRIBUTION. Very rare in the southern part of Eastern Siberia, common in the southern part of the Russian Far East, known from the only locality in the extreme East of Mongolia (Fig. 3)

HOST. On Salix nipponica Franch. et Savat. in Eastern Siberia, on Salix pierotii Miq. (section Subalbae) in the Russian Far East.

\section{Macropsis regalis Tishechkin, 1996}

Figs 4, 28-29, 76-78.

DISTRIBUTION. South-eastern Transbaikalia, southern part of the Russian Far East, eastern half of Mongolia (Fig. 4).

HOST. Was found only on S. schwerinii (section Viminella).

\section{Macropsis murina Tishechkin, 1998}

Figs 4, 26-27, 75.

DISTRIBUTION. South-eastern Transbaikalia, southern part of the Russian Far East, Eastern Mongolia (Fig. 4).

HOST. Was found only on S. schwerinii, often dwells together with $M$. regalis.

\section{Macropsis cerea (Germar, 1837) \\ Figs 3, 33-37, 83-92.}

Macropsis fieberi Ossiannilsson, 1938: 76 [synonymy by Tishechkin, 1998].
Macropsis kaahemica Vilbaste, 1980: 26-27, syn. n.

DISTRIBUTION. Transpalaearctic within the forest zone; known from several localities in Northern Mongolia (Fig. 3).

HOST. On different willow species.

REMARKS. Was recorded from Mongolia by Dlabola $[1965,1967 b, d]$.

M. kaahemica was described based on a single male with body length (including forewings) $4.70 \mathrm{~mm}$ from KaaKhem near Kyzyl, Tyva, Southern Siberia. The translation of the original description from Vilbaste [1980] is given below.

"Almost monochrome, light brown. Front part of body monochrome, only lateral part of pronotum, which is greatly expanding downward, whitish yellow, with large black-brown spot. Same, but lighter spot presents on rather sharp episternum of prothorax.

Scutellum with slightly more brownish basal triangles. Transverse scar very narrowly bordered by brown. Forewings more intense brown, very shiny, sometimes with whitish coating. Veins of same colour, only marginal vein (except apical margin) whitish."

In the course of our studies in Southern Siberia, including Tyva, we found only two species with brown coloration which fit this description, M. cerea (Figs 33-37) and $M$. flavida Vilbaste, 1980 (Figs 38-45). In both species, the dark pattern is very variable, so finding the specimen that matches the above description quite accurately is not difficult; among the specimens in the photographs these are males on Fig. 34 and, to a lesser extent, on Fig. 33.

According to our measurements of specimens from Mongolia, the body length (including forewings) of $M$. cerea males is $4.7-5.0 \mathrm{~mm}, 4.82 \pm 0.094, \mathrm{n}=15$ (range, mean \pm standard deviation, number of specimens measured), whereas
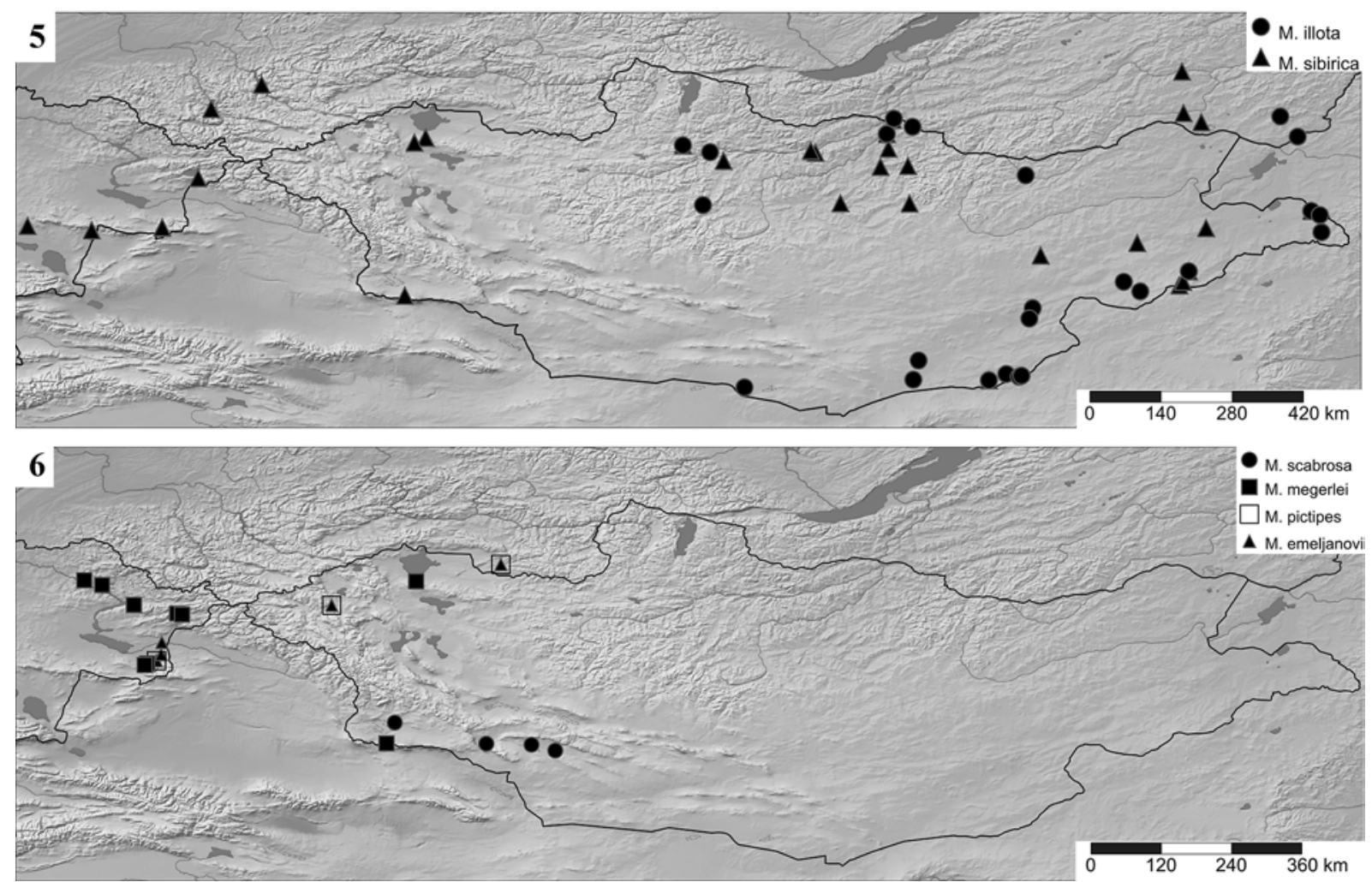

Figs 5-6. Maps of distribution of species of Macropsis in Mongolia and adjacent territories.

Рис. 5-6. Карты распространения видов рода Macropsis в Монголии и на сопредельных территориях. 


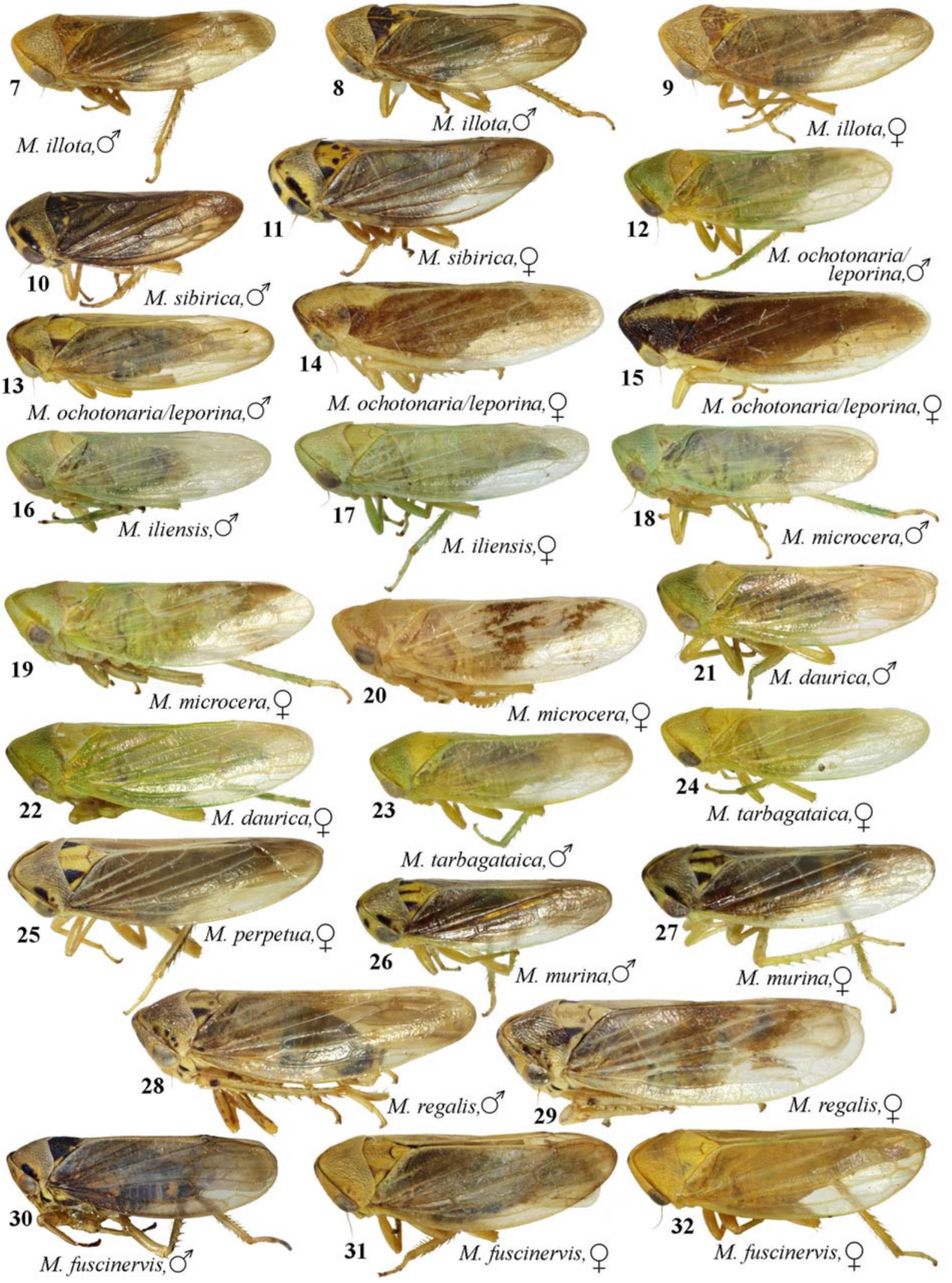

Figs 7-32. Macropsis spp., lateral view.

Рис. 7-32. Виды рода Macropsis, сбоку. 
in $M$. flavida it is $3.9-4.6 \mathrm{~mm}, 4.32 \pm 0.169, \mathrm{n}=30$. Thus, in the body length $M$. kaahemica falls into the variation range of M. cerea.
In $M$. cerea, penis in side view on average is wider than in M. flavida (cf. Figs 86-90 and 96-100). In this trait $M$. kaahemica (Fig. 91) also falls into the variation range of $M$.

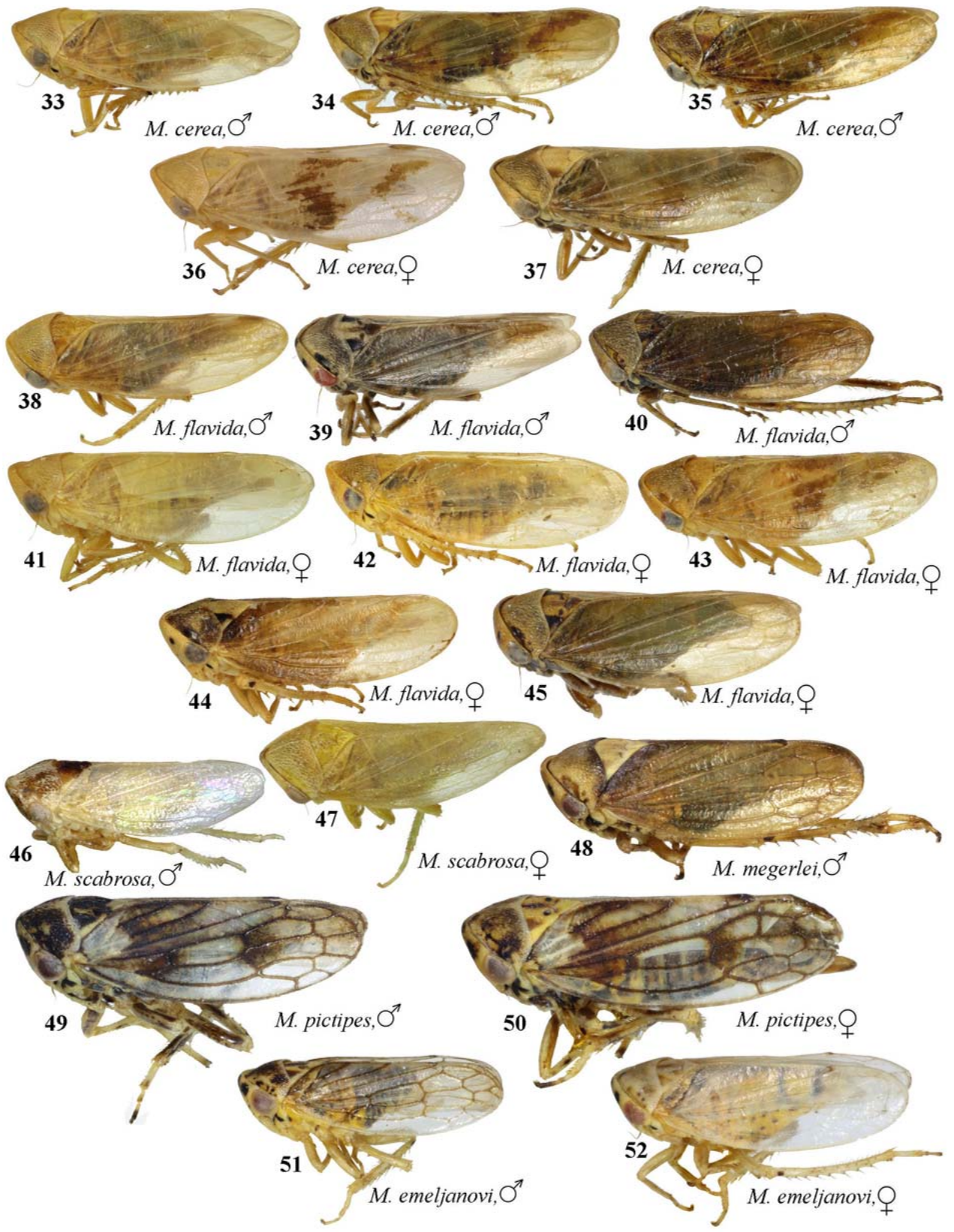

Figs 33-52. Macropsis spp., lateral view.

Рис. 33-52. Виды рода Macropsis, сбоку. 
cerea. For this reason we establish a synonymy $M$. cerea $($ Germar, 1837$)=$ M. kaahemica Vilbaste, 1980, syn. n.

It should be added, that $M$. cerea also differs from $M$. flavida in the shape of male $2^{\text {nd }}$ tergal apodemes (cf. Figs 83 85 and 93-95), in a number of subapical teeth on $2^{\text {nd }}$ valvulae of ovipositor (cf. Figs 92 and 101-102), and in male calling signal pattern, but these traits are not mentioned in the original description.

\section{Macropsis flavida Vilbaste, 1980}

Figs 4, 38-45, 93-102.

DISTRIBUTION. All Southern Siberia and the southern part of the Russian Far East; known from several localities in Northern and Eastern Mongolia (Fig. 4).

HOST. On different willow species.

REMARKS. Dlabola [1967b, d, 1970] records from Mongolia the European-Central Asiatic species, M. impura (Boheman, 1847) feeding on Salix rosmarinifolia L. (section Incubaceae) and closely related to $M$. flavida. Since $S$. rosmarinifolia occurs in Mongolia, the finding of $M$. impura here is possible. However, all specimens studied by us belong to M. flavida; in addition, we have never seen specimens of M. impura from localities east of Kazakhstan.

Macropsis multa Tishechkin, 1997

DISTRIBUTION. All Southern Siberia and the southern part of the Russian Far East; can be found in Northern Mongolia.

HOST. Salix brachypoda (Trautv. et Mey) Kom. (section Incubaceae) in Transbaikalia and the Russian Far East; outside its range in Irkutsk Oblast and Tyva was found on willows from the section Arbuscella.

Species dwelling on elms (Ulmus spp.). Two species, one of which occurs in Mongolia.

\section{Macropsis illota (Horvath, 1899)}

Figs 5, 7-9, 53-55.

Macropsis ulmaria Anufriev, 1971: 96-97 [synonymy by Tishechkin, 1998].

DISTRIBUTION. Eastern Transbaikalia, eastern half of Mongolia (Fig. 5), southern part of the Russian Far East, Northern China, and Japan. Introduced to Central Asia, Kazakhstan, and European Russia with ornamental U. pumila; penetrates to the north as far as the Moscow Oblast.

HOST. Ulmus pumila.

REMARK. Was recorded from Mongolia by Emelyanov [1977] as M. ulmaria.

Species dwelling on Spiraea spp. Two species, one of which occurs in Mongolia.

\section{Macropsis sibirica Kusnezov, 1929} Figs 5, 10-11, 56-58.

Macropsis obscurinervis Vilbaste, 1965: 31-32 [synonymy by Tishechkin, 1994].

DISTRIBUTION. Steppe zone of Palearctic from European Russia to Eastern Transbaikalia and Mongolia. One of the most common species throughout Mongolia.

HOST. Spiraea hypericifolia in European Russia, Kazakhstan, and Central Asia, S. aquilegifolia and, possibly, some other Spiraea species in Transbaikalia.

REMARK. Was recorded from Mongolia by Dlabola [1965, 1967b, 1968a] and Emelyanov [1977]; however, the figure in Dlabola [1965: 93, fig. 19] shows penis of some other Macropsis species (cf. Fig. 58).
Species dwelling on Rosa spp. Five species, one of which occurs in Mongolia.

\section{Macropsis megerlei (Fieber, 1868)}

Figs 6, 48, 106.

Macropsis venusta Emelyanov, 1964: 14-15 [synonymy by Tishechkin, 1994]

DISTRIBUTION. Europe, East Mediterranean (Turkey, Lebanon), Transcaucasia, Kazakhstan, Southern Siberia eastwards as far as the Baikal Lake, Western Mongolia.

HOST. Rosa spp.

REMARK. Was recorded from Mongolia by Emelyanov [1977] as M. venusta.

Species dwelling on sea-buckthorn (Hippophae rhamnoides). Three species, two of which occur in Mongolia.

16. Macropsis pictipes (Horvath, 1904)

Figs 6, 49-50.

Macropsis grossa Dubovskiy, 1966: 100-101[(synonymy by Tishechkin, 1994].

DISTRIBUTION. Eastern half of North Caucasus, mountains of Southern Kazakhstan and Central Asia, Southern Siberia (Tyva), North-western Mongolia.

HOST. Hippophae rhamnoides. Often dwells together with M. emeljanovi Dubovskiy, 1966.

REMARK. Was recorded from Mongolia by Emelyanov [1977] as M. grossa.

\section{Macropsis emeljanovi Dubovskiy, 1966}

Figs 6, 51-52, 107.

Macropsis pseudomulsanti Tishechkin, 1993: 55-57 [synonymy by Tishechkin, 2002].

DISTRIBUTION. Central Asia, Southern Kazakhstan, Southern Siberia (Tyva), North-western Mongolia, and China (Xinjiang).

HOST. Hippophae rhamnoides. Often dwells together with $M$. pictipes.

REMARKS. Was recorded from Mongolia by Emelyanov [1977] as M. mulsanti (Fieber, 1868).

In Eastern Kazakhstan, Southern Siberia, Mongolia, and China is represented only by yellowish brown colour variation. An emerald green variation, which is common in Tajikistan and Kyrgyzstan and occasionally occurs in Southern Kazakhstan, was not found in the eastern part of the range.

Species dwelling on desert poplars from the subgenus Turanga. This group includes one species occurring in deserts of Central Asia including Mongolia.

18. Macropsis scabrosa Korolevskaya, 1963 Figs 6, 46-47, 103-105.

DISTRIBUTION. Deserts and arid foothills of Central Asia, Southern Kazakhstan, and South-western Mongolia. HOST. Populus from the subgenus Turanga.

REMARK. Was recorded from Mongolia by Emelyanov [1977] as M. scabra (misprint).

Key to SPECIES OF MACROPSIS OF Mongolia

1. Male $2^{\text {nd }}$ tergal apodemes elongated, convergent, separated by large round notch, with more or less expanded tips (Figs 53-54). Penis comparatively narrow (Fig. 55). Body and forewings brown (Figs 7-9). On Ulmus pumila ..... M. illota (Horv.).

- Combination of characters is different ........................ 2 

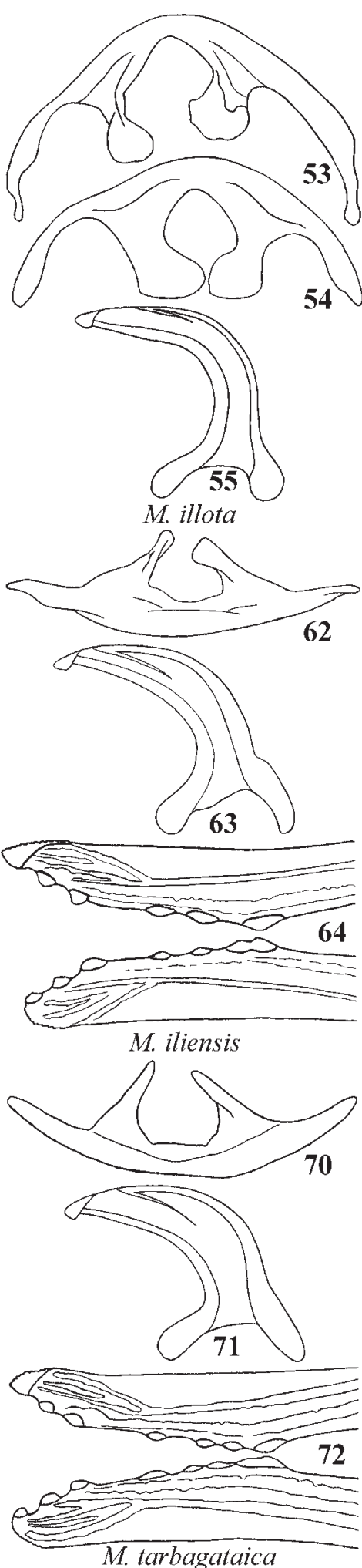

Figs 53-78. 53-55 - Macropsis illota; 56-58 - M sibirica; 59-61 - M ochotonaria / M leporina; 62-64-M iliensis: 65-67 - M. microcera; 68-69-M. daurica; 70-72 - M. tarbagataica; 73-74-M. perpetua; 75-M. murina; 76-78-M. regalis. 53-54, 56-57, 59,76 - male abdominal apodemes of the $2^{\text {nd }}$ tergite; $62,65,68,70,73-75,77$ - the $2^{\text {nd }}$ sternite; $55,58,60,63,66,69,71,78-$ penis, lateral view; $61,64,67,72-$ the $2^{\text {nd }}$ valvulae of ovipositor.

Рис. 53-78. 53-55 - Macropsis illota; 56-58 - M. sibirica; 59-61 - M. ochotonaria / M. leporina; 62-64-M. iliensis; 65-67 - M. microcera; 68-69 - M. daurica; 70-72 - M. tarbagataica; 73-74-M. perpetua; 75 - M. murina; 76-78 - M. regalis. 53-54, 56-57, 59, 76 - аподемы II брюшного тергита самца; 62, 65, 68, 70, 73-75, 77 - аподемы II брюшного стернита самца; 55, 58, 60, 63, 66, 69, 71,78 - пенис, сбоку; 61, 64, 67, 72 - внутренние створки яйцеклада. 
2. $2^{\text {nd }}$ tergal apodemes wide, rounded, separated by small round notch (Figs 56-57). Penis comparatively wide (Fig. 58). Pale yellow with black pattern, forewings semitransparent with black veins (Figs 10-11). On Spiraea M. sibirica Kusn

- Combination of characters is different ........................ 3

3. Penis in side view broad, usually bent at obtuse angle (Figs 60, 63, 66, 69, 71, 78, 81, 86-91, 96-100). On poplars and willows

- Penis in side view narrow, usually bent at right angle (Figs 105-107). On plants from other families .................. 15

4. Male $2^{\text {nd }}$ tergal apodemes long and wide, more or less parallel-sided, with widely rounded tips (Fig. 59). $2^{\text {nd }}$ valvulae of ovipositor with $8-13$ preapical teeth each (Fig. 61). Green (Fig. 12) or pale yellow with dark pattern (Figs 13-15); in female, yellow colour form usually brighter, with two dark longitudinal stripes on sides of the fore part of the body and with dark forewings with light costal margin (Figs 14-15) ....................................... 5 .

- $2^{\text {nd }}$ tergal apodemes shorter and/or narrower (Figs 76, 7980, 83-85, 93-95) .................................................. 6

5. On Salix from the section Helix.... M. ochotonaria Tish.

- On Salix from the section Viminella ..... M. leporina Tish.

6. Green or yellowish green (Figs 16-19, 21-24), only in $M$. microcera Vilb. female very occasionally pale yellowish with brown pattern on forewings (Fig. 20) ................. 7

- Brown, yellow, yellowish brown or reddish brown, often with dark pattern (Figs 25-45)

7. Pale emerald green (Figs 16-19), female very occasionally pale yellowish with brown pattern on forewings (Fig. 20)

- Bright yellowish green (Figs 21-24) ... 8

9

8. Male $2^{\text {nd }}$ sternal apodemes longer, strongly convergent, usually with expanded tips, separated by narrow gap (Fig. $62) .2^{\text {nd }}$ valvulae of ovipositor with 3-4 preapical teeth each (Fig. 64). Tarsi tips in male strongly darkened (Fig. 16). Smaller; $\sigma^{7}, 3.8-4.3 \mathrm{~mm}, 9,4.4-5.0 \mathrm{~mm}$

M. iliensis Mit

- Male $2^{\text {nd }}$ sternal apodemes rather short, triangular, separated by wide gap (Fig. 65). $2^{\text {nd }}$ valvulae of ovipositor with 10-12 preapical teeth each (Fig. 67). Tarsi tips in male light or only slightly darkened (Fig. 18). Larger; $\sigma^{7}, 4.2$ $4.8 \mathrm{~mm}, 0,4.8-5.4 \mathrm{~mm}$................. M. microcera Vilb.

9. Larger; $O^{\prime}, 4.3-4.9 \mathrm{~mm}$, $+4.6-5.6 \mathrm{~mm}$, male $2^{\text {nd }}$ sternal apodemes separated by wider gap (Fig. 68). Penis narrower (Fig. 69). $2^{\text {nd }}$ valvulae of ovipositor with 9-11 preapical teeth each (as in Figs 61, 67) .............. M. daurica Tish.

- Smaller; $0^{\top 7}, 3.8-4.3 \mathrm{~mm},+, 4.6-5.0 \mathrm{~mm}$, male $2^{\text {nd }}$ sternal apodemes separated by comparatively narrow gap (Fig. 70). Penis wider (Fig. 71). $2^{\text {nd }}$ valvulae of ovipositor with 4 preapical teeth each (Fig. 72) ......... M. tarbagataica Mit.

10 . Male $2^{\text {nd }}$ sternal apodemes strongly convergent, with lobes overlapping or touching each other (Figs 73-74). Yellowish with black spots on fore part of body (Fig. 25); forewings brown with light veins and occasionally with dark pattern .................................... M. perpetua Tish.

- Lobes of male $2^{\text {nd }}$ sternal apodemes separated by gap (Figs $75,77)$

11. Yellow with dark pattern, forewings semi-transparent ish with yellow costal margin (Figs 26-27). Small species; ऽ, 3.3-3.5 mm, , 3.6-3.9 mm .......... M. murina Tish.

- Pale yellowish or brown, forewings transparent with brown transverse stripes, brown, or reddish brown, with costal margin of the same colour or only slightly lighter than the main part (Figs 28-45). $\sigma^{7}$ larger than $3.9 \mathrm{~mm}$, 9 larger than $4.4 \mathrm{~mm}$
12. Very large species; $\sigma^{7}, 5.2-5.4 \mathrm{~mm},+$, $5.8-6.3 \mathrm{~mm}$. Forewings transparent with two more or less distinct transverse brown stripes (Figs 28-29). Male $2^{\text {nd }}$ tergal apodemes comparatively long, with more or less developed round notches on inner edges (Fig. 76). Penis wide, with distinct extension at bend (Fig. 78)

M. regalis Tish.

— oै smaller than $5.0 \mathrm{~mm}$, क smaller than $5.7 \mathrm{~mm}$. Male $2^{\text {nd }}$ tergal apodemes shorter, more or less rounded, with less developed if any notches on inner edges (Figs 79-80, 83$85,93-95)$. Forewings in male usually without transverse stripes ... frontal spot (Fig. 30); in darkest males upper part of head entirely black. Male $2^{\text {nd }}$ tergal apodemes comparatively narrow (Figs 79-80). Female yellowish, reddish brown, or brown (Figs. 31-32); occasionally, greenish. $2^{\text {nd }}$ valvulae of ovipositor with one preapical tooth each (Fig. 82); sometimes, small additional denticle presents on one valvula. On Populus tremula ........... M. . fuscinervis (Boh.)

- Face usually unmarked (Figs. 33-38, 40-43), only very occasionally with black spots (Figs. $39,44-45$ ). Male $2^{\text {nd }}$ tergal apodemes usually wider (Figs $83-85,93-95$ ). $2^{\text {nd }}$ valvulae of ovipositor with more than three preapical teeth each (Figs. 92, 101-102). On willows ............. 14

14. Penis in side view usually wider (Figs 86-91). Male $2^{\text {nd }}$ tergal apodemes with smooth outer margins (Figs 83-85). $2^{\text {nd }}$ valvulae of ovipositor with 4-6 preapical teeth each (Fig. 92). Larger; in populations from Mongolia, $O^{7}, 4.7-$ $5.0 \mathrm{~mm}$,, , 4.9-5.7 mm .................... M. cerea (Germ.)

- Penis in side view usually narrower (Figs 96-100). Outer margins of male $2^{\text {nd }}$ tergal apodemes often with denticle on one or both sides (Figs 93-95). $2^{\text {nd }}$ valvulae of ovipositor with 8-10 preapical teeth each (Figs 101-102). Smaller; in populations from Mongolia, $\sigma^{7}, 3.9-4.6 \mathrm{~mm}, 0,4.4$ $5.3 \mathrm{~mm}$............................................ M. flavida Vilb.

15. $2^{\text {nd }}$ tergal apodemes narrow triangular, usually longer than their width at base (Figs 103-104). Pale yellowish or greenish, male usually with dark pattern on head, pro-, and mesonotum, female often lacks any dark pattern (Figs 46-47). On Populus from the subgenus Turanga

M. scabrosa Kor.

- $2^{\text {nd }}$ tergal apodemes shorter, with widely rounded lobes (as in Figs. 94-95) .................................................... 16

16. Forewings uniformly brown (Fig. 48). On Rosa ............

M. megerlei (Fieb.)

- Forewings semi-transparent, usually with dark pattern and/or partially darkened veins (Figs 49-52). On Hippophae rhamnoides

15. Larger, $\bigcirc^{7}, 4.5-5.0 \mathrm{~mm}, 9,5.3-6.1 \mathrm{~mm}$ (Figs 49-50) .... ............................................. M. pictipes (Horv.).

- Smaller, o', 3.4-3.7 mm, o, 4.2- $4.5 \mathrm{~mm}$ (Figs 51-52)... M. emeljanovi Dub.

\section{Conclusions}

Altogether, 18 species of Macropsis were found in Mongolia; probably, at least three more species can be found there, but they are absent in the studied materials.

As can be seen from the distribution maps, the most part of species occurs in northern half of Mongolia, i. e. in a forest and steppe zones. This is due to the fact that all Macropsis species are associated with trees and shrubs. Most species can be classified into four groups. 
The first group includes two European-Siberian species, M. microcera and M. megerlei, distributed from Europe up to the Baikal Lake and reaching Western Mongolia by the easternmost parts of their ranges.
The second group includes species, the main parts of the ranges of which are located in Kazakhstan, Kyrgyzstan and, partially, Tajikistan; to the east they penetrate no further than the western half of Mongolia. These
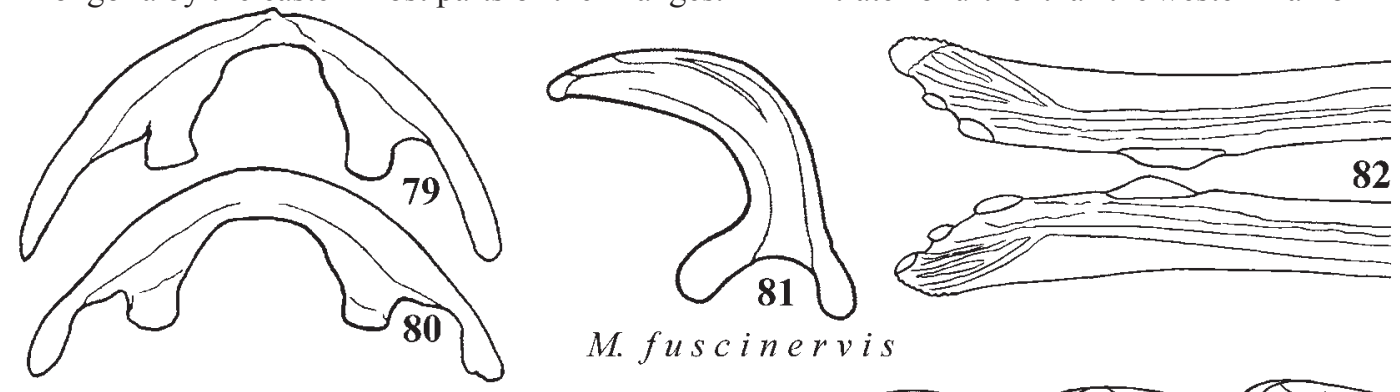

M. fuscinervis
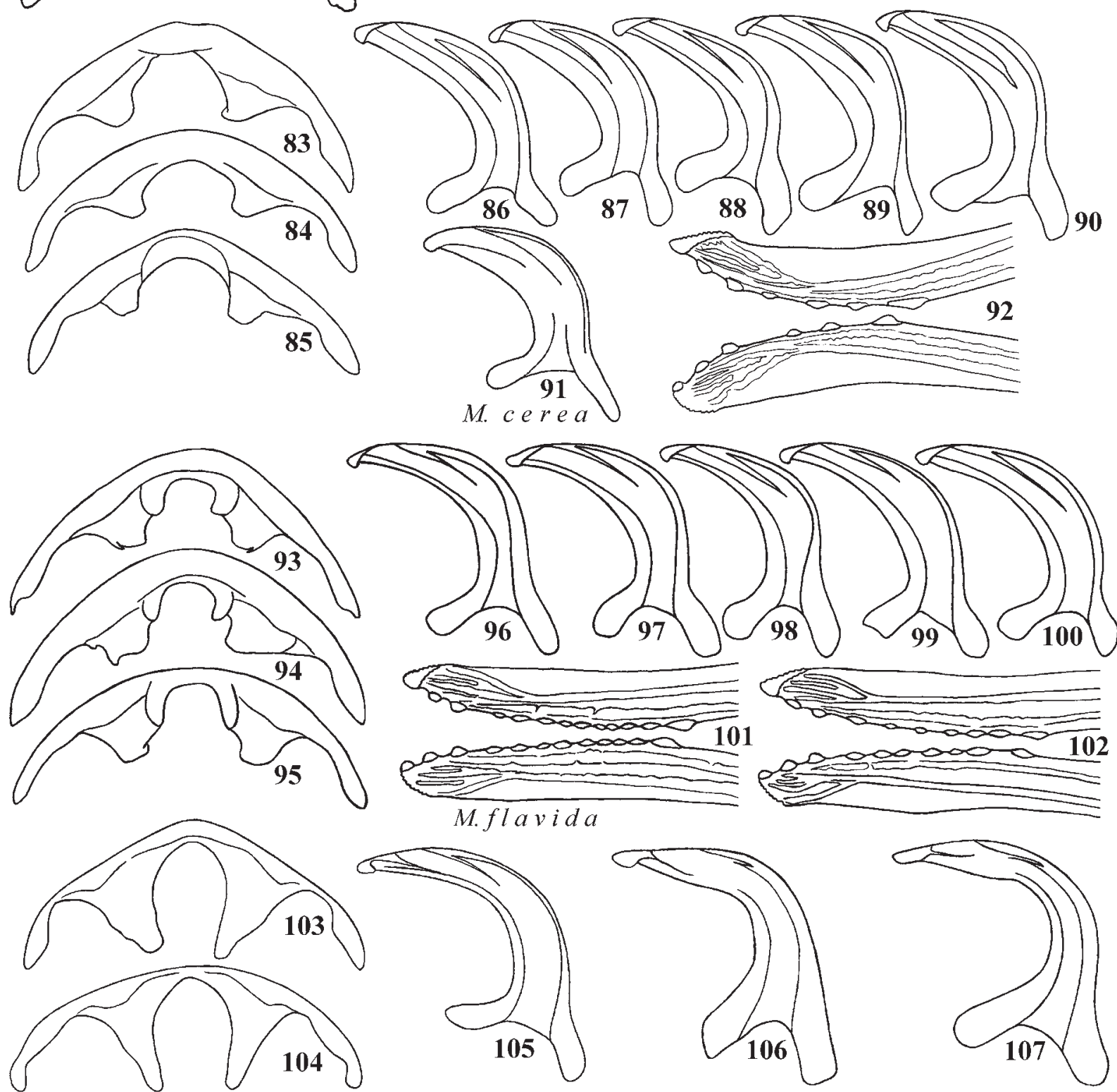

M. scabros a

$M$ megerlei

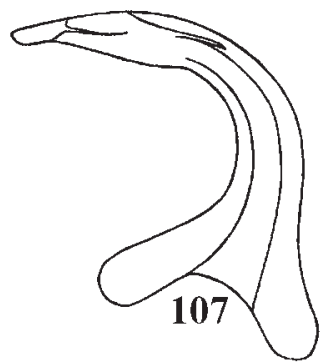

Figs 79-107. 79-82 - Macropsis fuscinervis; 83-92 - M. cerea; 93-102 - M. flavida; 103-105 - M. scabrosa; 106 - M. megerlei 107 - M. emeljanovi. 79-80, 83-85, 93-95, 103-104 - male abdominal apodemes of the $2^{\text {nd }}$ tergite; 81, 86-91, 96-100, 105-107 — penis, lateral view (91 - holotype of M. kaahemica; after Vilbaste, 1980); 82, 92, 101-102 - the $2^{\text {nd }}$ valvulae of ovipositor.

Рис. 79-107. 79-82 - Macropsis fuscinervis; 83-92 - M. cerea; 93-102 - M. flavida; 103-105 - M. scabrosa; $106-$ M. megerlei; 107 - M. emeljanovi. 79-80, 83-85, 93-95, 103-104 - аподемы II брюшного тергита самца; 81, 86-91, 96-100, 105-107 - пенис, вид сбоку (91 - голотип M. kaahemica; по: Вильбасте, 1980); 82, 92, 101-102 - внутренние створки яйцеклада. 
are M. tarbagataica, M. iliensis, M. pictipes, M. emeljanovi, and M. scabrosa.

The third group includes five East Siberian-Far Eastern species, M. daurica, M. perpetua, M. regalis, $M$. murina, and M. leporina. They reach eastern half of Mongolia in the westernmost parts of their ranges.

The fourth group includes four species occurring throughout all Southern Siberia and reaching the northern regions of Mongolia. These are transpalaearctic $M$. fuscinervis and M. cerea and the Siberian-Far Eastern M. flavida and M. ochotonaria.

The remaining two species are not associated with forest or riparian trees or shrubs; therefore, they are more widespread in Mongolia than others. M. illota dwells on Ulmus pumila, which is one of the most xerophyte tree species in Central Asia growing in the steppe and desert zones in temporary river beds; due to this, M. illota is widespread throughout Eastern Mongolia, including desert regions. M. sibirica feeds on steppe shrubs from the genus Spiraea and inhabits the steppe zone of Palaearctic; it occurs throughout steppes of Mongolia, but does not penetrate the desert regions.

No Macropsis species endemic for Mongolia were revealed.

Acknowledgements. I am most grateful to Prof. Alexander Emelyanov and Dr. Vladimir Gnezdilov (Zoological Institute of Russian Academy of Sciences, St.-Petersburg, Russia) for the kind permission to study the rich collection materials on Macropsini from Mongolia. The study was carried out in the framework of the Russian State program No. AAAA-A16-116021660095-7 with the support of Moscow State University Grant for Leading Scientific Schools "Depository of the Living Systems" in frame of the MSU Development Program.

\section{References}

Dlabola J. 1965. Ergebnisse der zoologischen Forschungen von Dr. Z Kaszab in der Mongolei. 54. Homoptera - Auchenorrhyncha // Acta faunistica entomologica Musei Nationalis Pragae. Vol.11. No.100. P. $79-136$.

Dlabola J. 1966. Ergebnisse der mongolisch-deutschen Expeditionen 1962 und 1964, Nr. 16: Homoptera, Auchenorrhyncha // Acta entomologica Bohemoslovaca. Vol.63. P.440-452.

Dlabola J. 1967a. Ergebnisse der 1. mongolisch-tschechoslowakischen entomologisch-botanischen Expedition in der Mongolei. Nr. 1: Reisebericht, Lokalitätenübersicht und Beschreibungen neuer Zikadenarten (Homopt. Auchenorrhyncha) // Acta faunistica entomologica Musei Nationalis Pragae. Vol.12. No.115. P.1-34.

Dlabola J. 1967b. Ergebnisse der 1. mongolisch-tschechoslowakischen entomologisch-botanischen Expedition in der Mongolei. Nr. 3: Homoptera Auchenorrhyncha (Ergänzung) // Acta faunistica entomologica Musei Nationalis Pragae. Vol.12. No.118. P. 51-102.
Dlabola J. 1967c. Ergebnisse der zoologischen Forschungen von Dr. Z. Kaszab in der Mongolei. Nr. 122: Homoptera - Auchenorrhyncha// Acta faunistica entomologica Musei Nationalis Pragae. Vol.12. No.123. P.137-152.

Dlabola J. 1967d. Ergebnisse der 2. mongolisch-tschechoslowakischen entomologisch-botanischen Expedition in der Mongolei // Acta faunistica entomologica Musei Nationalis Pragae. Vol.12. No.131. P.207-230.

Dlabola J. 1968a. Ergebnisse der zoologischen Forschungen von Dr. Z. Kaszab in der Mongolei. Nr. 169: Homoptera - Auchenorrhyncha// Acta faunistica entomologica Musei Nationalis Pragae. Vol.13. No.137. P.23-36.

Dlabola J. 1968b. Ergebnisse der zoologischen Forschungen von Dr. Z. Kaszab in der Mongolei. Nr. 163: Homoptera, Auchenorrhyncha // Acta entomologica Bohemoslovaca. Vol.65. P.364-374.

Dlabola J. 1970. Ergebnisse der zoologischen Forschungen von Dr. Z. Kaszab in der Mongolei. 220. Homoptera: Auchenorrhyncha // Acta zoologica academiae scientarum hungaricae. Vol.16. No.12. P.1-25.

Emelyanov A.F. 1972. [New Auchenorrhyncha from the Mongolian People's Republic] // Nasekomye Mongolii. No.1. P.199-260 [in Russian].

Emelyanov A.F. 1977. [Leafhoppers (Homoptera, Auchenorrhyncha) from the Mongolian People's Republic based mainly on materials of the Soviet-Mongolian zoological expeditions (19671969)] // Nasekomye Mongolii. No.5. P.96-195 [in Russian].

Emelyanov A.F. 1982. [Fulgoroidea (Homoptera) collected in the Mongolian People's Republic by the entomofaunistical group of the Soviet-Mongolian complex biological expedition in 19701975] // Nasekomye Mongolii. No.8. P.69-122 [in Russian].

Nast J. 1972. Palaearctic Auchenorrhyncha (Homoptera). An annotated check list. Warszawa, Polish Scientific Publishers. 550 pp.

Tishechkin D.Yu. 1994. [On the taxonomy of Palaearctic species of the genus Macropsis (Homoptera, Cicadellidae, Macropsinae)] / / Zoologicheskiy Zhurnal. Vol.73. No.7-8. P.42-51 [in Russian with English summary].

Tishechkin D.Yu. 1998. [New data on the taxonomy of leafhoppers of the genus Macropsis (Homoptera, Cicadellidae) from the eastern regions of Russia and adjacent territories] // Zoologicheskiy Zhurnal. Vol.77. No.4. P.417-430 [in Russian with English summary].

Tishechkin D.Yu. 1999. Review of the species of the genus Macropsis Lewis, 1834 (Homoptera: Cicadellidae: Macropsinae) from the Russian Far East and adjacent territories of Transbaikalia // Russian Entomol. J. Vol.8. No.2. P.73-113.

Tishechkin D.Yu. 2002. Review of the species of the genus Macropsis Lewis, 1834 (Homoptera, Cicadellidae, Macropsinae) from European Russia and adjacent territories // Russian Entomol. J. Vol.11. No.2. P.123-184.

Tishechkin D.Yu. 2014. Review of species of the genus Macropsidius Ribaut, 1952 (Homoptera: Cicadellidae: Macropsinae) of Russia and adjacent territories // Russian Entomol. J. Vol.23. No.3. P.155-167.

Tishechkin D.Yu. 2016. Host plant shifts and transitions into new adaptive zones in leafhoppers: the example of Macropsinae (Homoptera: Auchenorrhyncha: Cicadellidae) of Russia and adjacent countries // Zootaxa. Vol.4121. No.2. P.117-132.

Tishechkin D.Yu. 2020. Review of the genus Macropsis (Homoptera: Auchenorrhyncha: Cicadellidae: Eurymelinae: Macropsini) of South-eastern Kazakhstan with description of a new species // Zootaxa. Vol.4838. No.3. P.381-405.

Vilbaste Yu.G. 1980. [Fauna of Cicadinea of Tuva]. Tallinn: "Valgus" Publishers. 219 pp. [In Russian with English summary] 